\title{
INVECTIVE LEXIS AS A MEANS OF EXPRESSING VERBAL AGRESSION (BASED ON ENGLISH PERIODICALS)
}

\section{LEXIS INVECTIVO COMO MEDIO DE EXPRESAR AGRESIÓN VERBAL (BASADO EN PERIÓDICOS INGLÉS)}

\author{
Olga I. Abramova', Leila M. Garaeva ${ }^{1}$ \\ ${ }^{1}$ Kazan Federal University \\ o.abramova.11@mail.ru \\ $+79172657915$
}

Enviado: 27 de junio de 2019

Aceptado para publicar: 30 de julio de 2019

Publicado: 8 de agosto de 2019

\begin{abstract}
The present article reveals injective vocabulary as a means of expressing verbal aggression (on the material of the Independent, The Times, The Guardian periodicals, as well as in Internet comments on news and articles). The analysis of articles with injective vocabulary was carried out by the method of continuous sampling. The relevance of this article is due to the fact that in the sociolinguistic aspect verbal aggression is considered as a consequence of the unfavorable sociocultural position in society, growth of asociality, general decline in the level of speech culture, vulgarization of speech, propaganda of violence in the media, a significant weakening of communication and going online. The author reveals the essence of verbal aggression as a sociolinguistic phenomenon, cites the positions of the authors: A.D. Vasilyeva, T.A. Vorontsova, O.S. Korobkova, Z. D Popova, I. A Sternina, Ya. L. Fedorova, N. S. Yakimova, Barbieri F., Dong N., Cornips L., Inkpen D., Luzón, MJ, Ricoeur P., Saggion H., Shaffer K., Sumath C., Trieschnigg D., Volkova S., Yea Jang J. The author proposes a grouping of actual invective vocabulary: 1) Internet jargon; 2) vocabulary, indicating the inferiority of various kinds (verbalization of physical or spiritual impairment); 3 ) physiological deficiencies in the satisfaction of the natural needs of the person, as well as organs and parts of the body; 4) the opposition "yours is a stranger"; 5) offensive nominations for people based on race, nation (division into "white" and "black", true British and Europeans); 6) courses; 7) statements threatening life and health. The author provides examples of offensive language in the English media for each group. Special attention is paid to ethnopolitics. In the examples, the author focuses on evaluative interjections and particles, familiar references, colloquial expressions, colloquial vocabulary, reduced style vocabulary, and offensive nominations and exaggerations. The author comes to the conclusion that injective vocabulary, which has mobility and dynamism as a level of the language system, communicative and cognitive functions, represents, on the one hand, a verbal form of expressing the aggressive behavior of a person, on the other hand, a means of destructive influence on the interlocutor.
\end{abstract}

Keywords: invective lexicon, verbal aggression, invective, insult, conflict potential.

El presente artículo revela vocabulario inyectivo como un medio para expresar la agresión verbal (en el material de los periódicos independientes, The Times, The Guardian, así como en comentarios de Internet sobre noticias y artículos). El análisis de artículos con vocabulario inyectivo se realizó mediante el método de muestreo continuo. La relevancia de este artículo se debe al hecho de que, en el aspecto sociolingüístico, la agresión verbal se considera como consecuencia de la posición sociocultural desfavorable en la sociedad, el crecimiento de la asocialidad, el declive general en el nivel de la cultura del habla, la vulgarización del habla, la propaganda de la violencia en los medios, un debilitamiento significativo de la comunicación y la conexión. El autor revela la esencia de la agresión verbal como un fenómeno sociolingüístico, cita las posiciones de los autores: A.D. Vasilyeva, T.A. Vorontsova, O.S. Korobkova, Z. D Popova, I. A Sternina, Ya. L. Fedorova, NS Yakimova, Barbieri F., Dong N., Cornips L., Inkpen D., Luzón, MJ, Ricoeur P., Saggion H., Shaffer K., Sumath C., Trieschnigg D., Volkova S., Yea Jang J. El autor propone una agrupación de vocabulario invectivo real: 1) jerga de Internet; 2) vocabulario, que indica la inferioridad de varios tipos (verbalización del impedimento físico o espiritual); 3) deficiencias fisiológicas en la satisfacción de las necesidades naturales de la persona, así como de los órganos y partes del cuerpo; 4) la oposición "el tuyo es un extraño"; 5) nominaciones ofensivas para personas basadas en raza, nación (división en "blanco" y "negro", verdaderos británicos y europeos); 6) cursos; 7) declaraciones que amenazan la vida y la salud. El autor proporciona ejemplos de lenguaje ofensivo en los medios de comunicación en inglés para cada grupo. Se presta especial atención a la etnopolítica. En los ejemplos, el autor se enfoca en interjecciones y partículas evaluativas, referencias familiares, expresiones coloquiales, vocabulario coloquial, vocabulario de estilo reducido y nominaciones ofensivas y exageraciones. El autor llega a la conclusión de que el vocabulario inyectivo, que tiene movilidad y dinamismo como nivel del sistema del lenguaje, las funciones comunicativas y cognitivas, representa, por un lado, una forma verbal de expresar el comportamiento agresivo de una persona, por otro. mano, un medio de influencia destructiva en el interlocutor.

Palabras clave: léxico invectivo, agresión verbal, invectivo, insulto, potencial de conflicto. 


\section{Introduction}

The current stage of the existence of mass media in the Internet space is characterized not only by the freedom of thought and word but also by verbal aggression. The relevance of studying the phenomenon of verbal aggression in the media is dictated by the tension in the world: instability is observed in the socio-economic, political, interethnic and interethnic spheres of modern society on a global scale, along with interpersonal conflicts and is reflected in destructive verbal actions in periodicals, Internet comments to read news.

In the sociolinguistic aspect, verbal aggression is seen as a result of an unfavorable socio-cultural situation in society, an increase in asociality, a general decline in the level of speech culture, the vulgarization of speech, propaganda of violence in the media, a significant weakening of communication, and going online.

\section{Methods}

The study aims to investigate invective lexicon as a means of expressing verbal aggression.

The material of the study was articles of periodicals Independent, The Times, The Guardian, as well as in Internet comments on news and articles. The analysis of articles with injective vocabulary was carried out by the method of continuous sampling.

\section{Results and Discussion}

According to Ya. L. Fedorova, the phenomenon of verbal aggression should be associated with conflict-specific speech behavior, the desire to disrupt communication in a destructive speech form.

P. Ricoeur considers not only physical forms of violence but also verbal, the means of which is language: threats, insults, etc. [3]

The author argues that verbal aggression is a negative model of the behavior of communicants in the absence of a constructive strategy of cooperation and partnership [3].

Barbieri, F., Saggion H. believed that verbal aggression is a characteristic of the communicative portrait of a person, manifesting itself differently in each person. Verbal aggression as a personal characteristic indicates the nature of conflict-causing behavior since the personality selects a certain set of methods and means of destructive speech influence on the interlocutor [5].

According to Smith, C., Inkpen D., verbal aggression in the media focuses on a wide range of readers both in periodicals on paper and in the online medium, which is characterized by the fact that any reader can leave their comments, reflecting their attitude to this or that news article. At the same time, the Internet text of the media, as a rule, is characterized by greater verbal aggression, which is connected, first of all, with the promptness of putting articles and news on the site and almost instant response of readers [9].

Z. D Popova and I. A Sternin point out that the Internet text of the media is distinguished by its special character, since it initially laid down aggressive attitudes, the explicit meaning of which is reflected in verbal aggression through invective lexical units. The authors also point to the habit of aggression in the modern online environment [4].

Volkova, S., Shaffer K., Yea Jang J. in the study of verbal aggression note that the familiarity and routine of modern invective vocabulary lead to the fact that their conflict potential is gradually reduced, that is, invectives are included in the arsenal of journalists and readers. in turn, it necessitates the creation of new injective lexical units with a strong destructive and psychological effect [6].

According to A.D. Vasiliev, any word represents potential aggressiveness and offensiveness. In the necessary context, any word can receive a deliberate aggressive charge and become a verbal attack by the interlocutor.

According to N. S. Yakimova, invective vocabulary as a means of expressing verbal aggression includes evaluative interjections and particles, familiar references, colloquial expressions, colloquial vocabulary, reduced style vocabulary and offensive nominations and exaggerations [2].

Based on the opinion of TA Vorontsova, we note that an insult as a common type of verbal aggression in English periodicals is expressed through injective lexicon [1]:

- obscene name (Too little, too late for sloppy City, A sloppy piece of journalism; Optimism, cock-eyed or clear-eyed)

- zometaphor (I am a dinosaur, a Luddite, I am a dinosaur, a Luddite, I am a dinosaur, I'm not a caretaker, I'm not a caretaker I still hate it)

- accusations of violation of the bribe of the bribery of the bribery

- a characteristic of reduced vocabulary ('Scumbag 'Straw's unglamorous job).

According to the analysis, it is worth noting that the replacement of the name of the interlocutor, the replacement of a specific person with a collective value by an offensive name is a conscious rhetorical device. In the examples above, the Independent replaces the Manchester City football team, the journalist himself, the individual with invectives.

O.S. Korobkova [2], Dong N., Trieschnigg D., Cornips L. [7] note that verbal aggression, referred to as "hate speech language", 
characterized as a linguistic expression of social, national, religious, ethnic aggression, is the most common in the Western media. At the same time, statements are made out as a negative attitude towards another group through specific lexical means with a characteristic meaning - most often, discrimination, ethnic enmity, and the "friend-foe" opposition are the implicit meaning. In this regard, it is advisable to designate such a layer of lexical means in ethnophaulic in the injective lexicon, a term denoting by its internal form negative connotation in the name of another ethos.

According to Luzón, M.J., classic examples of ethnophaulic are motivated by an ethnonym word when there is an internal attitude of refusing or rejecting an ethnos as a representative of an alien ethnos [8]. The author notes that the injectivity of vocabulary can affect any social group: the attitude of the elite towards ordinary people (Gentlemen hobos with a story to tell.), the attitude to the lower social class, attitudes towards politicians (We're no longer cattle, we're communists, saying farewell to the past!), attitudes toward pseudo-patriots (Putman), toward the country (rushka), president (idiot).

The Independent, The Times articles concerning D. Trump use the word idiot and the more aggressive invective moron as an offensive name, to which the writer is negative. In this case, most often this word functions as a statement of fact:

1) Google hearing sees 'idiot' trending

2) Typing "idiot" into Google Images search reveals pictures of President Trump

3) That was followed by users of the website Reddit posting articles that contained pictures of President Trump alongside the word "idiot", in an attempt to manipulate the search engine database, in a practice known as Google bombing.

Or a question:

Idiot: Why Donald Trump face day show when you type 'idiot' for the internet?

A special place in verbal aggression is occupied by the verbalization of mental inferiority. The most frequent is the use of the adjective idiot, as well as such variations as a moron, with additional "human" characteristics:

1) Trump is not only a moron - but Rex Tillerson also says he is 'undisciplined,' 'doesn't like to read' and tries to break the law

2) Former Secretary of State Rex Tillerson, who called Trump a "moron" while he was in office, from which he was later fired, has expressed some more choice thoughts on the president.

An analysis of invective vocabulary as a means of verbal aggression in the Independent, The Times, The Guardian periodicals, as well as in Internet commentaries on news and articles allowed to divide it into the following groups:

1. Internet lingo (Noob, trolling, meme)
2. Vocabulary, indicating the inferiority of various kinds (verbalization of physical or spiritual impairment). For example: From 'colored' to 'cripple' - some words just don't belong in everyday language; The Cripple of Inishmaan West End Tickets)

3. Physiological deficiencies in meeting the natural needs of the person, as well as organs and body parts. For example:

1) Homophobic and transphobic abuse: 'Beaten up for looking gay'

2) Jack Gunter was beaten by two men who kicked him in the face and called him "faggot" and "queer".

3) The 22-year-old said last year's attack was the latest homophobic abuse act he has suffered since coming out aged 13 .

3) LGBT+ charity Stonewall Cymru said homophobic and transphobic bullying was a common experience for young people.

4) Recalling the attack, Mr. Gunter said: "They shouted faggot across the street. They punched me to the floor and one of them kicked me in the face."

5) An Aberdeen councilor has been cleared of making homophobic comments towards the authority's gay then-leader.

6) Jim Farquharson admitted calling John Stewart a "fascist" and a "fat git" but Mr. Stewart claimed the term "faggot" had been used.

The emphasis on the physique by means of bad visuals, for example:

1) "Oops, sharpie boobs. - Damn it wardrobes department, you had one job!" - Australian newsreader makes a boob with unfortunate outfit choice (via Independent Entertainment)

2) Song labeling gay couple 'fairy' and 'fag' is not homophobic, court rules

4. Opposition "your - someone else." The actual invective lexeme, which includes the national component, is Russophobe and rushka.

1) I am described as a "Pathological Russophobe" and listed as such in a pictorial rogues' gallery alongside Boy George, Stephen Fry, Peter Tatchell and a host of international luminaries. Well, sorry to disappoint you, tovarich, but I love Russia. I have enjoyed visiting several times, even though before the Moscow Olympics they tried to confiscate a sports magazine in which I interviewed Sebastian Coe as "bourgeois propaganda" and bugged our rooms.

2) Trump is portrayed here as an outsider: "the upstart with no connection to the ruling class", according to Komsomolskaya Pravda.

3) Russian media have been portraying Donald Trump as the outsider in the US election

4) Hillary Clinton is seen as a Russophobe

5. The division into "white" and "black", the true British and Europeans - offensive nominations, denoting people based on race, nation.

For example: 
RACISM IS RIFE ON DATING APPS WHERE DOES IT COME FROM AND HOW CAN IT BE FIXED?

1) The comments posted on@GrindrRacism are shocking and range from the blunt ("only into white guys") to the downright hideous: "shouldn't [black people] be in the fields, picking cotton?"

"I saw a guy on Grindr recently who's profile read: 'No whites. Sorry, that's just my preference'," he said.

This group should include ethnophaulic - words with negative connotations, calling representatives of a certain ethnicity or nationality. It should be noted that the content of negative connotation reflects a certain meaning $[7,12]$.

For example, the frequency is ironic and crude ethnopolitics. To ironic include: Abbie (male Jew, from Abraham), ABC (American-born Chinese, applies to Chinese who were not born in Ape (the token refers to black, based on the theory that humans are descended from chimpanzees), Ali Baba (ethnopolitics refers to Iraqi citizens suspected of terrorism or other crimes), Coconut (a man of South Asian origin, with dark skin, assimilated into European culture). The rude include: Ching Chong imitates the tone sound of the language), Fritz (German, from the German name Friedrich), Frog (French, based on the association with the favorite French dish "frog legs") $[8,11]$.

1) If you see Fritz, tell him it's time for ' $T$ '

2) This is the trouble with the EU, it's all one way. British citizens are allowed to live and work in Europe without a visa, then in return, we're supposed to let them live and work here, without even having a visa. It's like when you go around someone's house and they make you a cup of tea. Then when they visit you, they expect you to make THEM a cup of tea, the cheeky bastards.

3) "This morning I had a productive and encouraging discussion with Monsieur Barnier of the EU, and the one remaining sticking point is they come over here, bleedin' hordes of them, like bloody ants they are, they get off the boat, go straight down the council and they're given a hovercraft for free, just like that, I'm telling you."

6. Swear words

1) Chester Bennington discusses his depression in 'final' interview: 'I can either just give up and $\mathrm{f}^{*}$ cking die or I can fight'

For example, as illustrated in the below screenshots, some profiles explicitly state racial preferences (e.g., "no African girls").

2) See, when you don't know, you try desperately to find out. But the minute you think you know, the minute you go $\mathrm{Oh}$ yeah, we've been here before, no sense reinventing the wheel, you stop learning, stop questioning, and start believing in your wisdom, you're dead. You're not stupid anymore, you are fucking dead."

3) Damn those Europeans 'jumping the queue' and taking all those jobs we'd rather not do anyway

7. Threatening life and health statements.

1) Die, damn you - 've got money on it...

2) "I never felt like anyone wanted me dead before," says Kendall Morrison, a 35-year-old New Yorker with Aids. But the Michigan investigator who purchased Morrison's life insurance policies five years ago certainly seems to.

\section{Summary}

Thus, the mobility and dynamism of invective vocabulary as a level of the language system allows journalists to use not only the familiar set of readers of language tools but also to create their arsenal of invectives. Particularly obvious for the creation and subsequent use of invective lexicon in the media are the events and changes taking place in society, which are perceived quite sensitively by both journalists, bloggers, and philistines.

\section{Conclusion}

Thus, injective vocabulary, which has mobility and dynamism as a level of the language system, communicative and cognitive functions, represents, on the one hand, a verbal form of expression of aggressive behavior of a person, on the other hand, a means of destructive influence on the interlocutor.

\section{Acknowledgments}

The work is performed according to the Russian Government Program of Competitive Growth of Kazan Federal University.

\section{References}

1. Vorontsova, T. A. Trolling and flaming: verbal aggression in Internet University. Series: History and Philology. 2016. - Vol. 26. Vol. 2. - pp. 109-116.

2. Korobkova, O. S. Markers of hate speech in the nominations of ethnicity: a sociolinguistic aspect // News of the RSPU. A.I. Herzen. - 2009. - № 111. - pp. 200-205.

3. Ricoeur, P. Conflict of interpretations / P. Ricoeur. - M .: Academic Project, 2008. $704 \mathrm{p}$.

4. Sternin, I. A. Social factors and the development of modern Russian // Theoretical and applied linguistics. Issue 2. Language and social environment. Voronezh, 2000. P. 4-16. URL: http://philology.ru/linguistics2/sternin00.htm (appeal date: 03/24/2019). 
5. Barbieri, F., Saggion H. (2014). Modeling irony in Twitter: Feature analysis and evaluation. In Conference Conference, pages 4258-4264, Reykjavik.

6. Dahler-Larsen, P. (2014). Effects of getting beyond unintended consequences. Public Management Review, 16, pages 969986.

7. Dong N., Trieschnigg D., Cornips L. (2015). Audience and the use of minority languages twitter. In Proceedings of ICWSM, pages 666-669.

8. Luzón, M.J. (2013). Recontextualizing scientific discourse for a diversified audience. Written Communication, 30 (4), pages $428-457$.

9. Sumath, C., Inkpen D. (2015). How much does micropost data help in sentiment analysis? In Proceedings of the 6th Workshop on Computational Approaches to Subjectivity, Sentiment and Social Media Analysis, pages 115-121, Lisbon.

10. Volkova, S., Shaffer K., Yea Jang J. (2017). Separating facts from fi action: Linguistic models for classifying suspiciously and trusted posts on Twitter. Meeting of the Association for Computational Language, volume 2, pages 647-653.

11. Zare, Z. (2015). The benefits of ebusiness adoption: an empirical study of Iranian SMEs. UCT Journal of Management and Accounting Studies, 3(1), 6-11.

12. Mendes, I. A., \& Silva, C. A. F. D. (2018). Problematization and Research as a Method of Teaching Mathematics. International Electronic Journal of Mathematics Education, 13(2), 41-55. https://doi.org/10.12973/iejme/2694 